\title{
Perbedaan Kepuasan Kerja Karyawan Hotel yang Dipimpin oleh Pemimpin Ekspatriat dan Pemimpin Lokal
}

\author{
Ni Komang Dewi Sikiani dan Supriyadi \\ Program Studi Psikologi, Fakultas Kedokteran, Universitas Udayana \\ dewi.sikiani@gmail.com
}

\begin{abstract}
Abstrak
Dengan adanya globalisasi, menghadirkan suatu fenomena yang dinamakan Masyarakat Ekonomi ASEAN (MEA). Salah satu tujuan MEA adalah meningkatkan daya saing kawasan secara keseluruhan di pasar dunia, khususnya ASEAN (Susilo, 2010). Hal ini menunjukkan mudahnya akses pekerja asing atau ekspatriat yang hendak bekerja di Indonesia, ataupun sebaliknya. Bali menduduki posisi lima teratas yang memiliki jumlah ekspatriat terbanyak di Indonesia. Sektor pariwisata di Bali juga mengalami peningkatan serta jumlah pemimpin ekspatriat pada hotel di Bali yang meningkat. Dengan adanya pemimpin ekspatriat dan pemimpin lokal, tentunya kepuasan kerja karyawan pada hotel akan beragam.

Tujuan penelitian ini adalah untuk mengetahui perbedaan kepuasan kerja karyawan hotel yang dipimpin pemimpin ekspatriat dan pemimpin lokal. Subjek penelitian ini diambil dengan metode simple random sampling hingga mendapatkan 72 sampel dari dua hotel bintang empat yaitu Hotel Mercure Bali Nusa Dua dan Hotel Mercure Bali Legian. Metode pengambilan data menggunakan skala kepuasan kerja dengan koefisien Cronbach's Alpha $(\alpha=0,970)$. Analisis uji beda Independent Sample T-Test menunjukkan signifikansi (2-tailed) 0,311 yang artinya tidak terdapat perbedaan kepuasan kerja karyawan yang dipimpin oleh pemimpin ekspatriat dan pemimpin lokal.
\end{abstract}

Kata Kunci: Kepuasan Kerja, Pemimpin Lokal, Pemimpin Ekspatriat

\begin{abstract}
The existence of globalization presents a phenomenon called Asean Economic Community (AEC). One of AEC's objectives is to improve the competitiveness of the overall region in world market, especially ASEAN (Susilo, 2010). This indicates the open access of foreign workers or expatriates who want to work in Indonesia, or vice versa. Bali ranked in the top five positions with the largest number of expatriates in Indonesia. The tourism sector in Bali has also increased and the number of expatriate leaders in hotels at Bali has increased. With the expatriate leaders and local leaders, employee's job satisfaction at the hotel would vary.

The purpose of this research is to know the job satisfaction differences of hotel employees led by expatriate leader and local leader. The subjects of this study were taken by simple random sampling method to get 72 samples from two fourstar hotels that is Mercure Bali Nusa Dua Hotel and Mercure Bali Legian Hotel. Method used for data collection was job satisfaction scale with Cronbach's Alpha coefficient $(\alpha=0,970)$. Independent Sample T-Test showed the significance (2-tailed) is 0,311 which means there is no significant difference between job satisfaction of hotel employees led by expatriate leader and local leader.
\end{abstract}

Keywords : Job satisfaction, Expatriate Leader, Local Leader 


\section{LATAR BELAKANG}

Globalisasi memberikan pengaruh yang besar dalam dunia industri dan organisasi yaitu menghubungkan kegiatan industri dan organisasi menjadi tanpa batas. Sektor industri dan organisasi di Indonesia juga merasakan pengaruh dari globalisasi. Hal ini ditandai dengan meningkatnya industri dan organisasi yang bergerak dalam ranah internasional. Batasan dalam negara tidak mampu membatasi persaingan industri yang berasal dari negara asing sehingga memunculkan persaingan yang lebih ketat.

Pengaruh globalisasi mendatangkan sebuah fenomena yaitu Masyarakat Ekonomi ASEAN (MEA) atau ASEAN Economic Community (AEC). MEA adalah bentuk integrasi ekonomi ASEAN yang dicapai pada tahun 2015 (Susilo, 2010). Tujuan MEA menurut Departemen Perdagangan RI (dalam Susilo, 2010) adalah menjaga stabilitas politik dan keamanan regional ASEAN, meningkatkan daya saing kawasan secara keseluruhan di pasar dunia, mendorong pertumbuhan ekonomi, dan mengurangi kemiskinan serta meningkatkan standar hidup penduduk negara ASEAN.

Berdasarkan tujuan MEA, salah satunya adalah meningkatkan daya saing kawasan secara keseluruhan di pasar dunia, khususnya ASEAN (Susilo, 2010). Hal ini menunjukkan mudahnya akses pekerja asing yang hendak bekerja di Indonesia, ataupun sebaliknya. Ekspatriat juga merupakan pekerja asing. Ekspatriat adalah warga negara yang tinggal dan bekerja di negara lain (Meija, Balkin \& Cardy, 2010). Ekspatriat yang ditugaskan umumnya ditempatkan pada posisi yang penting dalam perusahaan. Para ekspatriat ini ditempatkan pada top level management (Mathis \& Jackson, dalam Jati, Hamied \& Hakam, 2015). Top level management adalah tingkatan manajemen tertinggi dalam organisasi yang bertanggung jawab terhadap keseluruhan aktivitas organisasi, seperti direktur, presiden direktur, direksi (BOD), Chief Executive Officer (CEO), General Manager (GM), Managing Director (MD) (Astuty, 2015).

Seiring dengan fenomena MEA, berbagai perusahaan di Indonesia merekrut ekspatriat demi tercapainya kesuksesan dalam perusahaan. Pengajuan ijin ekspatriat selama 2014 meningkat drastis dibanding tahun sebelumnya. Berdasarkan data Kementrian Ketenagakerjaan (dalam Arief, 2015), sepanjang 2014 jumlah ekspatriat yang masuk ke Indonesia sebanyak 103.250 orang, meningkat dibanding 2013 yang hanya 97.654 orang. Lonjakan ekspatriat tersebut diyakini lantaran adanya peningkatan nilai investasi ke Tanah Air pada tahun lalu (Arief, 2015).

Berdasarkan data Badan Koordinasi Penanaman Modal (BKPM) (dalam Arief, 2015), investasi pada 2014 mencapai Rp. 463,1 triliun, meningkat $16,2 \%$ dari tahun sebelumnya yang hanya Rp. 398,6 triliun. Jakarta menjadi daerah tertinggi yang ditempati oleh ekspatriat dengan 51.550 (49,93\%), disusul Jawa Barat dengan 16.225 (15,71\%), Banten 6.026 (5,84\%), Kepulauan Riau 4.134 (4,00\%), Bali sebanyak 3.850 $(3,73 \%)$, dan Jawa Timur dengan 2.728 (2,64\%). Terkait dengan level jabatan, profesional menempati posisi teratas dengan 35.735 (34,61\%), kemudian disusul advisor atau konsultan $20.562(19,91 \%)$, manajer 16.354 (15.84\%), serta teknisi 13.923 (13,48\%) (Arief, 2015). Hal ini membuktikan bahwa ekspatriat di Indonesia banyak memegang posisi top level management di berbagai industri maupun organisasi.

Bali menduduki posisi lima teratas yang memiliki jumlah ekspatriat terbanyak di Indonesia. Hal tersebut menunjukkan bahwa Bali telah menjadi pulau yang mengikuti arus globalisasi untuk menwujudkan salah satu manfaat MEA yaitu meningkatkan daya saing kawasan secara keseluruhan di pasar dunia, khususnya ASEAN (Susilo, 2010). Berdasarkan data Dinas Tenaga Kerja dan Transmigrasi Provinsi Bali (dalam Wahyura, 2015), jumlah ekspatriat sesuai penerbitan Izin memperkerjakan Tenaga Kerja Asing (IMTA) bulan Juni 2015 berjumlah 1.837 orang. Jumlah ini mengalami kenaikan dibanding pada bulan desember tahun 2013 dengan jumlah 1.802 orang, dan naik menjadi 1.856 pada desember 2014. Hal yang melandasi tingginya jumlah ekspatriat bekerja di Bali karena pertumbuhan industri dan pariwisata yang mengalami kenaikan telah mengikat para ekspatriat untuk bekerja serta mudahnya perpanjangan izin bekerja (Kristianto, 2014). Para ekspatriat di Bali juga banyak yang mendapatkan gaji dalam bentuk mata uang asing khususnya dollar Amerika Serikat hal tersebut yang menguntungkan pihak eskpatriat dan meningkatkan minat mereka untuk berkerja di Bali (Kristianto, 2015). Banyak ekspatriat yang mendirikan perusahaan atau bekerja sebagai General Manager (GM) dalam sektor wisata (Suryaniti dalam Kristianto, 2014). Hal ini menunjukkan kesempatan secara nyata ekspatriat untuk bekerja dalam sektor wisata.

Peningkatan jumlah ekspatriat pada sektor wisata di Bali seiring dengan tren Psikologi Industri dan Organisasi dalam dunia kerja, salah satunya tren ke-4 yaitu meningkatnya globalisasi dalam bisnis (Riggio, 2009). Semakin tingginya persaingan industri hingga ranah internasional meningkatkan kebutuhan tenaga kerja untuk dilatih di luar negeri maupun mendatangkan tenaga kerja dari luar negeri (Riggio, 2009). Salah satu sektor wisata di Bali adalah sektor perhotelan.

Pemimpin dalam hotel memegang peranan yang besar. Hal ini ditandai dengan kesuksesan hotel sangat ditentukan oleh kemampuan manajer atau pimpinan untuk beradaptasi dalam lingkungan internasional, serta dinamis dan penuh dengan berbagai peluang dan tantangan (Cahyono, 2014). Oleh karena itu, hotel tentunya mencari pemimpin dengan kualifikasi yang lebih ketat dan memperluas area pemilihan pemimpin.

Pemilihan pemimpin ekspatriat maupun pemimpin lokal dapat berdampak pada kepuasan kerja karyawan. Menurut model dari kepuasan kerja yang dikemukakan oleh Lawler (dalam Wijono, 2010) bahwa individu akan merasa puas terhadap bidang tertentu dari pekerjaan mereka misalnya, hubungan antara rekan kerja, atasan dan bawahan, dan/atau gaji. Individu dapat menerima dan melaksanakan pekerjaannnya dengan senang hati dalam bidang yang dia persepsikan, maka hasilnya akan sama dengan jumlah yang ia persepsikan dari yang secara aktual diterima (Wijono, 2010). Kepuasan kerja dapat berdampak terhadap produktivitas, ketidakhadiran dan keluarnya karyawan serta berdampak pada kesehatan (Munandar, 2014). Kepuasan kerja yang positif dapat ditinjau melalui hubungan positif antara pemimpin dan karyawannya 
(Munandar, 2014). Oleh karena itu, pemimpin dapat berkontribusi terhadap kepuasan kerja karyawan.

Adapun kasus yang terjadi pada karyawan yang dipimpin oleh pemimpin ekspatriat pada penelitian Perdana (2008) di PT. Astra Daihatsu Motor-Casting Plant. Dalam penelitian tersebut terjadi ketidakpuasan kerja dikarenakan komunikasi yang tidak efektif dan efisien antara ekspatriat dan karyawan lokal. Komunikasi yang tidak efektif dan efisien terjadi ketika perintah dari atasan terkadang sulit untuk ditafsirkan dan bersifat ambigu (Perdana, 2008).

Adapun hasil penelitian Nur (2016) bahwa terdapat ketidakpuasan kerja pada kepemimpinan ekspatriat di PT Gemopia Indonesia. Ketidakpuasan karyawan terhadap gaya kepemimpinan terlihat dari hubungan antara pemimpin dan karyawan. Pengaruh negatif yang dirasakan karyawan adalah ketidaknyamanan saat bekerja sehingga berdampak pada penurunan kinerja karyawan (Nur, 2016).

Hasil preliminary study pada subjek yang pernah bekerja di hotel Mercure Bali Nusa Dua. Berdasarkan wawancara preliminary study pada subjek W tanggal 6 oktober 2016, W menyatakan bahwa pernah mengalami ketidakpuasan kerja yang dikarenakan oleh atasan beliau saat bekerja di hotel Mercure Bali Nusa Dua. W merupakan salah satu mantan karyawan pada hotel Mercure Bali Nusa Dua. W merasa tidak puas dikarenakan tidak diberi cuti oleh atasannya. W awalnya telah melakukan request cuti selama tiga hari sejak satu bulan sebelum hari cuti tiba. Pada saat hari cuti W tiba, ia tiba-tiba tidak diberikan cuti oleh atasan beliau. W merasa bahwa ia telah melakukan request cuti sesuai prosedur namun tidak disetujui secara mendadak oleh atasan W. Kejadian tersebut membuat $\mathrm{W}$ memilih untuk resign dari hotel Mercure Bali Nusa Dua. Wawancara juga dilakukan kepada rekan kerja W yaitu A pada 6 november 2016 untuk mengonfirmasi pemaparan W. Berdasarkan wawancara dengan A, ia memberikan informasi bahwa alasan $\mathrm{W}$ resign dikarenakan oleh atasan $\mathrm{W}$ yang tidak memberikan hak cuti kepada W. A juga menginfokan bahwa atasan $\mathrm{W}$ pernah berkonflik dengan staf lainnya karena tidak memberikan cuti sakit dan tetap menyuruh staf tersebut untuk masuk walaupun staf sedang sakit. Pemimpin W pada saat itu merupakan pemimpin lokal namun general manager $\mathrm{W}$ adalah ekspatriat.

Berdasarkan pemaparan kasus diatas dapat disimpulkan bahwa pemimpin ekspatriat dapat saja mendatangkan ketidakpuasan kerja karyawan. Hal tersebut dapat dipicu dengan adanya perbedaan budaya yang dimiliki pemimpin ekspatriat dengan pemimpin lokal di Indonesia. Budaya yang dimaksud berbeda adalah budaya individualis dan budaya kolektif. Budaya individualis bertentangan dengan budaya kolektif. Budaya individualis memiliki nilai yang mendorong pengembangan individu secara otonom, unik, dan terpisah (Matsumoto \& Juang, 2013). Dalam budaya individualis, kebutuhan, keinginan, dan tujuan individu lebih diutamakan daripada tujuan kelompok (Matsumoto \& Juang, 2013). Adapun negara yang memiliki skor budaya individualis yang tinggi adalah Amerika Serikat, Australia dan Inggris (Matsumoto \& Juang, 2013). Budaya kolektif memiliki nilai bahwa individu saling ketergantungan dalam kelompok. Dalam budaya kolektif, individu mengorbankan kebutuhan dan tujuan pribadi mereka sendiri demi kepentingan umum (Matsumoto \& Juang, 2013). Matsumoto dan Juang (2013) mengelompokkan Indonesia memiliki skor budaya individualis yang rendah sehingga dapat dikatakan bahwa negara Indonesia termasuk dalam budaya kolektif.

Budaya berkaitan dengan nilai yang telah ditanamkan sejak dini oleh lingkungan, berdasarkan tempat seseorang berkembang (Matsumoto \& Juang, 2013). Nilai budaya dan tradisi dapat memengaruhi sikap dan perilaku dari para manajer dalam sejumlah cara berbeda (Yukl, 2007). Nilainya dapat diinternalisasikan oleh para manajer yang bertumbuh dalam satu budaya, dan nilai-nilai ini akan memengaruhi sikap serta perilaku mereka dalam cara yang mungkin tidak disadari (Yukl, 2007). Dalam organisasi yang matang dan relatif makmur, budaya memengaruhi pemimpin lebih daripada pemimpin yang memengaruhi budaya (Yukl, 2007). Para pemimpin juga harus mampu memahami bagaimana orang dari budaya berbeda memandang dan menerjemahkan tindakan pemimpin tersebut (Yukl, 2007). Dapat dikatakan bahwa budaya dapat memengaruhi sikap pemimpin, baik pemimpin lokal maupun pemimpin ekspatriat.

Adanya perbedaan budaya yang dimiliki oleh pemimpin ekspatriat dapat menyebabkan konflik salah satunya ketidakpuasan kerja karyawan di Indonesia. Kesulitan dalam penyesuaian budaya dapat saja terjadi pada pemimpin ekspatriat atau karyawan yang dipimpin oleh ekspatriat khususnya di Bali pada sektor pariwisata. Sektor pariwisata khususnya sektor perhotelan masih menjadi motor penggerak ekonomi di Bali sehingga pulau dewata ini akan sangat bergantung dari kinerja pariwisata pada sektor tersebut (Badan Pusat Statistika, 2016). Oleh karena itu, peneliti tertarik untuk menganalisis perbedaan kepuasan kerja karyawan hotel yang dipimpin oleh pemimpin ekspatriat dan pemimpin lokal.

\section{METODE PENELITIAN}

\section{Variabel dan Definisi Operasional}

Variabel dalam penelitian ini adalah kepuasan kerja sebagai variabel tergantung dan status kewarganegaraan pemimpin sebagai variabel bebas. Status kewarganegaraan pemimpin terdiri dari pemimpin ekspatriat dan pemimpin lokal.

Definisi operasional dari kepuasan kerja adalah penilaian dari pekerjaan seseorang terhadap berbagai aspek pekerjaannya serta hasil evaluasi karakteristik pekerjaannya, suatu perasaan senang atau bangga dari hasil persepsi karyawan yang berkaitan dengan pekerjannya. Semakin tinggi skor total aitem kepuasan kerja menunjukkan karyawan semakin puas dengan pekerjaan yang dijalani dan semakin rendah skor total aitem kepuasan kerja menunjukkan karyawan semakin tidak puas dengan pekerjaan yang dijalani.

Kepuasan kerja diukur dengan skala psikologis yang disusun berdasarkan faktor-faktor penentu kepuasan kerja menurut Locke, Siegel \& Lane (dalam Munandar, 2014). 
(1) Ciri-ciri intrinsik pekerjaan, yaitu ciri-ciri dari pekerjaan yang menentukan kepuasan kerja ialah keragaman, kesulitan, jumlah pekerjaan, tanggung jawab, otonomi, kendali terhadap metode kerja, kemajemukan, dan kreativitas, (2) Gaji, yaitu kepuasan kerja merupakan fungsi berdasarkan jumlah absolut dari gaji yang diterima, derajat sejauh mana gaji memenuhi harapan-harapan tenaga kerja, dan bagaimana gaji diberikan, (3) Penyeliaan, yaitu sejauh mana penyelia atau pemimpin membantu tenaga kerja, untuk memuaskan nilai-nilai pekerjaan yang penting bagi tenaga kerja, (4) Rekan-rekan sejawat yang menunjang, yaitu karyawan lain yang bekerja sama dengan seseorang terkait penyelesaian pekerjaan, (5) Kondisi kerja yang menunjang, yaitu kondisi kerja yang aman, layak, nyaman, menyenangkan baik secara psikis maupun psikologis.

\section{Responden}

Populasi dalam penelitian ini adalah seluruh karyawan hotel Mercure Bali Nusa Dua dan Mercure Bali Legian. Karakteristik subjek dalam penelitian ini adalah sebagai berikut: (1) Karyawan yang bekerja di hotel yang Mercure Bali Nusa Dua dan Mercure Bali Legian. Alasan pemilihan subjek yang bekerja di hotel tersebut karena Mercure Bali Legian dipimpin oleh pemimpin ekspatriat dan Mercure Bali Nusa Dua dipimpin oleh pemimpin lokal dan sama-sama dibawahi oleh perusahaan Accor, (2) Karyawan berjenis kelamin laki-laki atau perempuan, (3) Usia karyawan berkisar 25 tahun sampai 45 tahun, (4) Memiliki masa kerja minimal satu tahun, (5) Pendidikan terakhir minimal Sekolah Menengah Atas/Kejuruan.

\section{Tempat Penelitian}

Penelitian ini dilakukan pada hotel Mercure Bali Nusa Dua dan Mercure Bali Legian. Penyebaran skala dilakukan pada bulan Maret 2017 hingga bulai Mei 2017.

\section{Alat Ukur}

Alat ukur dalam penelitian ini menggunakan skala kepuasan kerja berdasarkan faktor-faktor penentu kepuasan kerja menurut Locke, Siegel \& Lane (dalam Munandar, 2014). Skala kepuasan kerja terdiri dari 58 aitem yang terdapat pernyataan positif (favorable) dan pernyataan negatif (unfavorable) dengan empat pilihan jawaban, yaitu sangat setuju (SS), setuju (S), tidak setuju (TS), dan sangat tidak setuju (STS).

Uji validitas alat ukur dalam penelitian ini dilakukan dengan mengeliminasi aitem-aitem yang memiliki skor corrected item-total correlation kurang dari 0,3 . Uji reliabilitas alat ukur dalam penelitian ini dilakukan dengan melihat nilai cronbach alfa $(\alpha)$ pada program SPSS 20.0 for windows.

Pengujian validitas skala kepuasan kerja dilakukan pada 60 aitem skala kepuasan kerja. Terdapat dua aitem yang memiliki nilai di bawah 0,3 sehingga aitem tersebut digugurkan dan jumlah aitem valid menjadi 58 aitem. Hasil uji validitas skala kepuasan kerja menunjukkan nilai koefisien korelasi aitem total bergerak dari 0,355 sampai 0,800 . Hasil uji reliabilitas skala kepuasan kerja menunjukkan koefisien alfa $(\alpha)$ sebesar 0,970 yang berarti skala kepuasan kerja mampu mencerminkan $97,0 \%$ variasi skor murni subjek, sehingga dapat disimpulkan bahwa skala kepuasan kerja layak untuk digunakan sebagai alat ukur tingkat kepuasan kerja.

\section{Metode Pengumpulan Data}

Metode pengumpulan data yang dilakukan dalam penelitian ini adalah simple random sampling. Metode simple random sampling dikatakan sederhana karena pengambilan anggota sampel dari populasi dilakukan secara acak tanpa memerhatikan strata yang ada dalam populasi itu (Sugiyono, 2014).

Jumlah skala yang disebar pada saat pengambilan data sebanyak 260 skala dengan total skala yang kembali sebanyak 191 skala. Sedangkan total skala yang dapat dianalisis sebanyak 72 skala dikarenakan skala lainnya tidak sesuai dengan kriteria subyek yang telah ditetapkan dan terdapat beberapa skala yang informasinya tidak lengkap.

\section{Teknik analisis data}

Metode analisis statistik yang digunakan adalah uji Independent Sample T-Test. Analisis ini berfungsi untuk mengetahui apakah ada perbedaan rata-rata mean antara dua populasi, dengan melihat rata-rata dua sampelnya (Santoso, 2003). Untuk melakukan analisis tersebut digunakan program SPSS. Apabila hasil analisis menunjukkan signifikansi kurang dari $0,05(\mathrm{p}<0,05)$ maka hipotesis alternatif dapat diterima.

\section{HASIL PENELITIAN}

\section{Karakteristik subjek}

Berdasarkan karakteristik usia, subjek terbanyak berusia dari rentang 24-28 tahun, yaitu sebanyak 39 subjek atau 28,08\% dari total subjek. Berdasarkan jenis kelamin, jumlah subjek laki-laki lebih besar dari pada subjek perempuan, yaitu sebanyak 55 subjek atau 39,6\% dari total subjek sedangkan subjek perempuan sebanyak 17 subjek atau 12,24\% dari total subjek. Berdasarkan karakteristik tingkat pendidikan terakhir, mayoritas subjek berpendidikan S1 pada hotel yang dipimpin ekspatriat yaitu 11 subjek atau $30,6 \%$ dari total subjek kategori ekspatriat sedangkan mayoritas subjek berpendidikan SMA pada hotel yang dipimpin lokal yaitu 16 subjek atau $44,5 \%$ dari total subyek kategori lokal. Berdasarkan lama bekerja, mayoritas subjek bekerja selama 22-31 bulan pada hotel yang dipimpin ekspatriat yaitu 28 subjek atau 77,8\% dari total subjek kategori ekspatriat sedangkan mayoritas subjek bekerja selama 12-21 bulan pada hotel yang dipimpin lokal yaitu 11 subjek atau 30,5\% dari total subjek kategori lokal.

\section{Deskripsi dan kategori data penelitian}

Hasil deskripsi data penelitian ditunjukkan pada Tabel 1. (Tabell.Deskripsi Data Penelitian. Terlampir). Pada tabel 1 menunjukkan bahwa mean teoretis pada kedua kelompok adalah sebesar 145 sementara mean empiris pada kelompok karyawan yang dipimpin oleh lokal sebesar 177,53 dan pada kelompok karyawan yang dipimpin oleh ekspatriat sebesar 183,03 . Perbedaan antara mean teoritis dan mean empiris pada dua kelompok ternyata terbukti berbeda secara signifikan $(\mathrm{t}$ lokal=9,072., $\quad \mathrm{p}=0,000$ sedangkan $\mathrm{t}$ ekspatriat $=9,445$., 
$\mathrm{p}=0,000)$. Oleh karena itu, dapat disimpulkan bahwa kedua kelompok subjek memiliki taraf kepuasan kerja yang tinggi.

\section{Uji Independent Sample T-test}

Uji hipotesis dilakukan dengan metode analisis Independent Sample T-Test dengan bantuan perangkat lunak SPSS. Tujuan dari uji hipotesis adalah untuk mengetahui apakah terdapat perbedaan rata-rata antara dua kelompok penelitian. Hipotesis alternatif (Ha) dalam penelitian ini adalah terdapat perbedaan kepuasan kerja karyawan hotel yang dipimpin oleh pemimpin ekspatriat dan pemimpin lokal.

Berdasakan hasil analisis Independent Sample T-Test, diperoleh F-test untuk kepuasan kerja adalah 0,735 dengan signifikansi 0,394 yang berada diatas $0,05(\mathrm{p}>0,05)$, maka data memiliki varian yang sama (Equal varian assumed). Nilai signifikansi atau $\mathrm{p}$ yang diperoleh sebesar 0,311 berada diatas $0,05(\mathrm{p}<0,05)$ dengan nilai t sebesar $[-1,020]$. Perbedaan mean antara kedua kelompok sebanyak 5,500 dengan standar eror 5,391. Dengan demikian dapat dikatakan bahwa hipotesis dalam penelitian yaitu terdapat perbedaan kepuasan kerja karyawan hotel yang dipimpin oleh pemimpin ekspatriat dan pemimpin lokal dalam penelitian ini dinyatakan ditolak. Hasil uji hipotesis penelitian dapat dilihat pada tabel 2. (Tabel 2. Rangkuman Uji Hipotesis. Terlampir Penelitian).

\section{PEMBAHASAN DAN KESIMPULAN}

Hasil uji hipotesis dengan Independent Sample T-Test menunjukkan perbedaan mean antara kedua kelompok sebanyak 5,500 dimana mean taraf kepuasan kerja kelompok karyawan yang dipimpin oleh lokal lebih rendah dibandingkan kelompok karyawan yang dipimpin oleh ekspatriat namun perbedaannya tidak signifikan. Nilai signifikansi dari uji Independent Sample T-Test adalah sebesar 0,311 sehingga dapat disebutkan bahwa tidak terdapat perbedaan yang signifikan pada kepuasan kerja karyawan hotel yang dipimpin oleh pemimpin ekspatriat dan pemimpin lokal.

Kepuasan kerja menurut Howell dan Dipboye (dalam Munandar, 2014) adalah hasil keseluruhan dari derajat rasa suka atau tidak sukanya tenaga kerja terhadap berbagai aspek dari pekerjaannya. Aspek maupun faktor penentu kepuasan kerja menurut Munandar (2014) terbagi menjadi ciri-ciri intrinsik pekerjaan, gaji penghasilan, penyeliaan, rekan kerja sejawat yang menunjang serta kondisi kerja yang menunjang. Penyeliaan adalah sikap yang terjadi antara atasan dan bawahan. Atasan yang dimaksud adalah pemimpin serta bawahan adalah karyawan pada hotel tersebut. Pemimpin termasuk komponen faktor dalam penentu kepuasan kerja. Hasil penelitian ini sejalan dengan pemaparan Munandar (2014) bahwa faktor-faktor yang memengaruhi kepuasan kerja bukan hanya penyeliaan melainkan terdapat empat faktor lainnya. Adapun teori lain menurut Locke (dalam Gruneberg, 1979) faktor-faktor yang memengaruhi kepuasan kerja adalah gaji, keamanan, kelompok kerja, supervisi, partisipasi, konflik peran dan ambiguitas, serta struktur organisasi dan iklim organisasi. Wijono (2010) juga menjelaskan faktor-faktor yang memengaruhi kepuasan kerja yaitu frustrasi dan pengasingan, ciri-ciri teknologi, kebermaknaan kerja, sifat- sifat supervisi, pekerjaan dan kesejahteraan psikologis, ketidaksesuaian peran dan konflik kerja. Oleh karena itu dapat disimpulkan bahwa kepuasan kerja tidak hanya dipengaruhi oleh supervisi dari pemimpin saja melainkan terdapat berbagai faktor lain yang juga berkontribusi.

Adapun kriteria kedua hotel yang digunakan dalam penelitian ini adalah setara. Kedua hotel berada dibawah perusahaan yang sama yaitu perusahaan Accor Hotel sehingga standar organisasi yang digunakan juga kurang lebih serupa. Accor Hotel merupakan perusahaan multinasional Perancis terbesar yang beroperasi di 92 negara (Accorhotels.com). Accor Hotel memiliki berbagai tipe serta merek hotel yang ditawarkan mulai dari economy brands (merek ekonomis), midscale brands (merek menengah), upscale brands dan luxury brands (merek atas dan mewah). Kedua hotel tergolong dalam kategori midscale brands atau setara dengan level bintang empat sesuai dengan Direktori Dinas Pariwisata Bali 2016. Perbedaan kedua hotel tersebut terlihat dari status kewarganegaraan general manager (GM) nya. GM hotel Mercure Bali Nusa Dua berkewarganegaraan Indonesia sedangkan GM hotel Mercure Bali Legian berkewarganegaraan Australia. Kedua GM tersebut memiliki latar belakang budaya yang berbeda. Indonesia tergolong dalam budaya kolektivisme sedangkan Australia tergolong dalam budaya individualisme (Matsumoto \& Juang, 2013). Dalam budaya individualisme, kebutuhan, keinginan, dan tujuan individu diutamakan daripada kelompok atau tujuan kolektif (Matsumoto \& Juang, 2013). Pada budaya kolektif, individu saling bergantung pada kelompok, mengorbankan kebutuhan dan tujuan pribadi demi kepentingan umum (Matsumoto \& Juang, 2013). Budaya yang berbeda dari pemimpin pada penelitian ini tidak menunjukkan perbedaan kepuasan kerja yang signifikan. Penelitian ini sejalan dengan pemaparan Bass (dalam Yukl, 2007) bahwa determinan budaya pemimpin tidak selalu kongruen dengan kepuasan kerja karyawan. Determinan lain yang dapat menentukan kepuasan kerja adalah tipe kepemimpinan dari pemimpin (Yukl, 2007). Oleh karena itu, pemimpin yang berasal dari budaya yang berbeda dapat saja menganut tipe kepemimpinan yang sama.

Sistem organisasi hotel yang diterapkan pada kedua hotel tersebut sudah dirancang oleh perusahaan sehingga GM perlu menyesuaikan sistem dari perusahaan tersebut. Hotel bintang 3 keatas umumnya telah memiliki sistem baku yang telah ditetapkan oleh perusahannya. Kedua hotel tersebut dapat digolongkan dalam tipe rancangan organisasi yang bernama birokrasi. Birokrasi adalah satu struktur dengan tugas-tugas yang beroperasi sangat rutin yang dicapai melalui spesialisasi (Munandar, 2014). Spesialisasi yang dimaksud adalah pengelompokan tugas-tugas ke dalam bagian-bagian fungsional tertentu, misalnya bagian keuangan, produksi, distribusi dan sebagainya (Munandar, 2014). Pada kedua hotel tersebut, terdapat berbagai spesialisasi untuk mengelompokkan tugas pada bagian-bagian fungsional seperti Food \& Beverage, Engineering, Front Office, Housekeeping, Financial/Accounting, Revenue/IT, Sales \& Marketing, dan Talent \& Culture Manager. Kekuatan utama dari organisasi berstruktur birokrasi terletak dalam kemampuannya untuk 
melakukan kegiatan-kegiatan yang distandarisasi dengan cara yang sangat efisien (Munandar, 2014). Oleh karena itu, bagian-bagian fungsional telah memiliki pemimpin serta sistem yang telah distandarisasi oleh perusahaan sehingga GM tidak memiliki peran yang besar dalam memimpin karyawannya.

Penelitian ini menghasilkan tidak terdapat perbedaan kepuasan kerja karyawan yang dipimpin oleh pemimpin ekspatriat dan pemimpin lokal karena sama-sama memiliki skor tinggi pada kepuasan kerja. Hasil penelitian ini sejalan dengan penelitian Jati, dkk (2015) menemukan bahwa kepemimpinan ekspatriat juga berpengaruh signifikan dan memiliki hubungan yang positif terhadap kepuasan kerja melalui komunikasi lintas budaya. Tidak ditemukannya perbedaan kepuasan kerja antara pemimpin lokal dan pemimpin ekspatriat pada penelitian ini menandakan bahwa pemimpin ekspatriat juga mampu memberikan hubungan positif pada kepuasan kerja yang sejalan dengan penemuan Jati, dkk (2015).

Keterbatasan dari penelitian ini adalah rantai organisasi dari GM hingga karyawan tergolong panjang. Hal tersebut menyebabkan karyawan cenderung tidak merasakan kepemimpinan dari GM langsung melainkan pemimpin dari masing-masing bagian fungsional. Keterbatasan kedua yaitu informasi jabatan pada bagian biodata tidak sepenuhnya diisi sesuai dengan jabatan karyawan namun diisi hanya dengan jabatan "staf" sehingga peneliti tidak dapat menjabarkan deskripsi kategorisasi pekerjaan. Keterbatasan ketiga yaitu penelitian ini tidak mengontrol proses kelekatan budaya yang dimiliki oleh pemimpin sehingga peneliti tidak memiliki data terkait budaya tersebut. Terakhir, pengambilan sampel yang kurang besar dan kurang bervariasinya tempat penelitian juga menjadi keterbatasan pada penelitian ini.

Berdasarkan penelitian yang telah dilakukan, dapat ditarik kesimpulan bahwa tidak terdapat perbedaan signifikan pada kepuasan kerja karyawan hotel yang dipimpin oleh pemimpin ekspatriat dan pemimpin lokal.

Berdasarkan kesimpulan yang sudah dipaparkan, maka dapat diberikan saran untuk pemimpin yaitu pemimpin hotel diharapkan dapat terus mengembangkan diri dalam memimpin hotel serta semakin memahami budaya organisasi yang dimiliki hotel. Pemimpin juga diharapkan dapat mempertahankan hal-hal positif yang mampu meningkatkan kepuasan kerja karyawan seperti menjalin hubungan positif dengan karyawannya. Saran bagi karyawan diharapkan dapat mempertahankan sikap kerja yang menunjang tingginya kepuasan kerja karyawan. Adapun saran bagi perusahaan adalah menjadi bahan pertimbangan untuk menambah kegiatan seperti refreshing atau mentoring yang dapat meningkatkan kepuasan kerja karyawan.

Saran lain yang dapat diberikan untuk peneliti selanjutnya yaitu perlu mengawasi proses pengisian jawaban yang diberikan, melakukan kontrol pendataan secara komprehensif terkait kriteria inklusi perusahaan dengan pemimpin ekspatriat dan pemimpin lokal dan menggunakan metode yang berbeda. Saran lain adalah memperhatikan rantai organisasi pada organisasi penelitian, meneliti tipe kepemimpinan yang digunakan oleh kedua pemimpin, menambah jumlah sampel penelitian dengan memperhitungkan waktu dan persiapan yang lebih matang. Saran terakhir adalah menambah dan mempertegas bahasan teori yang komprehensif untuk merumuskan kriteria pemimpin terkait dengan budaya yang dimiliki, tidak hanya melihat pada aspek kewarganegaraan yang dimiliki saja.

\section{DAFTAR PUSTAKA}

Aamodt, M. G. (2010). Industrial/organization psychology: An applied approach (6th edition). California: Wadsworth Cengage Learning.

Accorhotels.com. (2016). Diunduh dari accorhotels.com: https://www.accorhotels.com/gb/indonesia/index.shtml\#.

Anoraga, P. (1992). Psikologi kepemimpinan. Jakarta: PT Rineka Cipta.

Arief, T. (2015, Februari 19). Selama 2014, ijin tenaga kerja asing meningkat. Diunduh dari bisnis.com: http://industri.bisnis.com/read/20150219/12/404446/selama -2014-ijin-tenaga-kerja-asing-meningkat.

As'ad, M. (1995). Seri ilmu sumber daya manusia: Psikologi industri (edisi ke-4). Yogyakarta: Liberty Yogyakarta.

Astuty, T. (2015). Buku pedoman umum pelajar ekonomi: Rangkuman inti sari ekonomi lengkap. Jakarta: Vicosta Publishing.

Azwar, S. (2005). Tes prestasi: Fungsi pengembangan pengukuran prestasi belajar (edisi ke-2). Yogyakarta: Pustaka Pelajar.

Azwar, S. (2013). Metode penelitian. Yogyakarta: Pustaka Pelajar.

Azwar, S. (2014). Reliabilitas dan validitas. Yogyakarta: Pustaka Pelajar.

Azwar, S. (2015). Penyusunan skala psikologi. Yogyakarta: Pustaka Pelajar.

Badan Pusat Statistika. (2016). Provinsi Bali dalam angka (Bali province in figures). Bali: BPS Provinsi Bali.

Brahmasari, I.A., \& Suprayetno, A. (2008). Pengaruh Motivasi Kerja, Kepemimpinan dan Budaya Organisasi terhadap Kepuasan Kerja Karyawan serta Dampaknya pada Kinerja Perusahaan (Studi kasus pada PT. Pei Hai International Wiratama Indonesia). Jurnal Manajemen dan Kewirausahaan, 2(10), 124-135.

Cahyono, A.D. (2014). Analisis gaya kepemimpinan lintas budaya pada ekspatriat Korea Selatan dan Jepang di PT. Asahi Seiren Indonesia (ask-i). (Naskah tidak dipublikasikan). Program Studi Psikologi Universitas Brawijaya, Malang.

Dinas Pariwista Provinsi Bali. (2016). Direktori pariwisata Bali 2016. Denpasar: Dinas Pariwisata Provinsi Bali.

Emzir. (2012). Metodologi penelitian pendidikan: Kuantitatif dan kualitatif. Jakarta: Rajawali Pers.

Fatimah, F. N. D. (2015). Budaya kolektif sebagai prediktor kepuasan kerja, melalui keadilan prosedural pada karyawan perum perhutani di Jawa Tengah . (Skripsi tidak dipublikasikan). Fakultas Ilmu Sosial dan Humaniora Universitas Islam Negeri Sunan Kalijaga, Yogyakarta.

Ghozali, H. I. (2012). Aplikasi analisis multivariate dengan program IBM SPSS 20. Semarang: Badan Penerbit Universitas Dipenogoro.

Gruneberg, M.M. (1979). Understanding job satisfaction. London: British Library Cataloguing in Publication Data.

Hadi, S. (1977). Statistika 2. Yogyakarta: Penerbit Andi Offset.

Handoko, T. H. (2014). Manajemen personalia \& sumberdaya manusia. Yogyakarta: BPFE Yogyakarta.

Hasibuan, D. M. (2014). Manajemen sumber daya manusia. Jakarta: PT Bumi Aksara. 
Jati, L. S., Hamied, D., \& Hakam, M. S. (2015). Analisis pengaruh gaya kepemimpinan ekspatriat terhadap komunikasi lintas budaya dan job satisfaction karyawan (studi kasus gaya kepemimpinan ekspatriat di PT. Central Motor Wheel Indonesia). Jurnal Administrasi Bisnis, 2(25), 1-7.

Jex, S. (2002). Organization psychology. New York: John Wiley \& Sons.

King, L.A. (2010). Psikologi umum: Sebuah pandangan apresiatif. Jakarta: Salemba Humanika.

Kreitner, R., Kinicki, A., \& Cole, N. (2007). Fundamentals of organizational behavior. Toronto: McGraw-Hill Ryerson.

Kristianto, F. (2014, Juli 14). Tenaga kerja asing: Jumlah ekspatriat di Badung meningkat $10 \%$. Diunduh dari bisnis.com: http://kabar24.bisnis.com/read/20140714/78/243175/tenaga -kerja-asing-jumlah-ekspatriat-di-badung-meningkat-10.

Kristianto, F. (2015, Juni 11). Ekspatriat di Bali akan dibayarkan rupiah, melanggar ditindak polisi. Diunduh dari bisnis.com:

http://bali.bisnis.com/read/20150611/16/52344/ekspatriatdi-bali-akan-dibayar-rupiah-melanggar-ditindak-polisi.

Lumbanraja, P. (2010). Tantangan bagi kepemimpinan lintas budaya. Jurnal Manajemen Bisnis, 2(1), 59-68.

Luthans, F. (2006). Perilaku organisasi (edisi kesepuluh). Yogyakarta: Penerbit Andi.

Matsumoto, D \& Juang, L. (2013). Culture and psychology (fifth edition). Canada: Wadsworth Publishing.

Meija, L. R. G., Balkin, D. B., \& Cardy, R. L. (2010). Managing Human Resources: Global Edition. New Jersey: Pearson.

Munandar, A.S. (2014). Psikologi industri dan organisasi. Jakarta. Penerbit Universitas Indonesia.

Novrika, F. (2010). Desentralisasi dan gaya kepemimpinan sebagai variabel moderating dalam hubungan antara partisipasi penyusunan anggaran dan kinerja manajerial . (Skripsi tidak dipublikasikan). Fakultas Ekonomi Universitas Muhammadiyah, Surakarta.

Nur, B. (2016). Analisis Gaya Kepemimpinan Ekspatriat Korea Selatan terhadap Kinerja Karyawan di PT. Gemopia Indonesia. (Naskah tidak dipublikasikan). Universitas Gadjah Mada, Yogyakarta.

Olson, S. (2002). Mind mapping human history: Discovering the past through our genes. New York: Mariner Book.

Pamilih, I. (2014). Pengaruh independensi, gaya kepemimpinan, komitmen organisasi dan pemahaman good governance terhadap kinerja auditor pemerintah. (Naskah Publikasi). Fakultas Ekonomi dan Bisnis Universitas Muhammadiyah Surakarta, Surakarta.

Paripurna, I. G. D. (2013). Pengaruh kepemimpinan, lingkungan kerja dan komunikasi terhadap kepuasan kerja karyawan. E-Jurnal Manajemen Universitas Udayana, 5(2), 581-593.

Peraturan Menteri Ketenagakerjaan Republik Indonesia Nomor 16 Tahun 2015 tentang Tata Cara Penggunaan Tenaga Kerja Asing. Diunduh dari http://tkaonline.naker.go.id/pdf/PERMEN_16_TAHUN_2015.pdf.

Perdana, H. I. (2008). Analisis Pengaruh Konflik Terhadap Kinerja Karyawan (Studi Kasus Pt. Astra Daihatsu Motor - Casting Plant). (Naskah tidak dipublikasikan). Institut Pertanian Bogor, Bogor.

Potu, A. (2013). Kepemimpinan, motivasi, dan lingkungan kerja pengaruhnya terhadap kinerja karyawan pada KANWIL DITJEN kekayaan negara Suluttenggo dan Maluku Utara di Manado. Jurnal Emba, 4 (1), 1208-1218.

Pratama, C. Y. (2012). Pengaruh gaya kepemimpinan otokratis terhadap kepuasan kerja. Jurnal of Social and Industrial Psychology, 1 (2), 22-27.

Priyatno, D. (2012). Belajar praktis analisis parametrik dan non parametrik dengan SPSS.Yogyakarta: Gava Media.
Riduwan, M. B. (2012). Skala pengukuran variabel-variabel penelitian. Bandung: Alfabeta.

Riduwan., Rusyana, A., \& Enas. (2011). Cara mudah belajar SPSS versi 17.0 dan aplikasi statistik penelitian. Bandung: Alfabeta.

Riggio, R.E. (2009). Introduction to industrial/organizational psychology: 5th edition. New Jersey: Pearson Prentice Hall.

Riyadi, S. (2011). Pengaruh kompensasi finansial, gaya kepemimpinan, dan motivasi kerja terhadap kinerja karyawan pada perusahaan manufaktur di Jawa Timur. Jurnal Manajemen dan Kewirausahaan, 1 (13), 40-45.

Robbins, S. P. (2005). Organizational behavior. New Jersey: Pearson Prentice Hall

Robbins, S. P., \& Judge, T.A. (2013). Organizational behavior (fifteenth edition). New Jersey: Pearson.

Rochimawati \& Rachman, R. A. (2015, Desember 30). Menakar dampak positif dan negatif MEA terhadap indonesia. Diunduh dari viva.co.id: http://nasional.news.viva.co.id/news/read/717164-menakardampak-positif-dan-negatif-mea-terhadap-indonesia.

Santoso, S. (2003). Mengatasi berbagai masalah statistik dengan SPSS versi 11.5. Jakarta: PT Elex Media Komputindo.

Santoso, S. (2005). Menguasai statistik di era informasi dengan SPSS. Jakarta: PT Elexmedia Komputindo.

Sarwono, S.W \& Meinarno, E.A. (2009). Psikologi sosial. Jakarta: Salemba Humanika.

Sihite, R. (2000). Hotel management (pengelolaan hotel). Surabaya: SIC.

Sugiyono. (2014). Metode penelitian kuantitatif, kualitatif, dan kombinasi (mixed methods). Bandung: Alfabeta.

Surya, I. M. (2016, April 1). Badung catat 1.365 TKA bekerja sektor pariwisata. Diunduh dari antarabali.com: http://www.antarabali.com/berita/88476/badung-catat1365-tka-bekerja-sektor-pariwisata.

Susilo, Y.S. (2010). Strategi meningkatkan daya saing UMKM dalam menghadapi implementasi CAFTA dan MEA. Buletin Ekonomi, 2(8), 70-170.

Undang-Undang Republik Indonesia Nomor 13 Tahun 2003 tentang Ketenagakerjaan.

Wahyura, A. (2015, November 3). Jepang penyumbang tenaga kerja asing terbesar di Bali. Diunduh dari tribunnews.com: http://bali.tribunnews.com/2015/11/03/jepangpenyumbang-tenaga-kerja-asing-terbesar-di-bali.

Wexley \& Yukl. (1984). Organizational behavior and personnel psychology. Illinois: Richard D. Irwin, Inc.

Wijono, S. (2010). Psikologi industri \& organisasi: dalam suatu bidang gerak psikologi sumber daya manusia. Jakarta: Kencana Predana Media Group.

Wijono, S. (2012). Psikologi industri \& organisasi dalam suatu bidang gerak psikologi sumber daya manusia. Jakarta: Kencana Predana Media Group.

Winarsunu, T. (2002). Statistik dalam penelitian psikologi dan pendidikan. Malang: Penerbitan Universitas Muhammadiyah Malang.

Yukl, G. (2007). Kepemimpinan dalam organisasi: edisi Kelima. Jakarta: Indeks. 


\section{LAMPIRAN}

Tabel 1

Deskripsi data penelitian

\begin{tabular}{llllllll}
\hline Kelompok & $\mathbf{N}$ & $\begin{array}{l}\text { Mean } \\
\text { Teoretis }\end{array}$ & $\begin{array}{l}\text { Mean } \\
\text { Empiris }\end{array}$ & $\begin{array}{l}\text { Standar } \\
\text { Deviasi } \\
\text { Teoritis }\end{array}$ & $\begin{array}{l}\text { Standar } \\
\text { Deviasi } \\
\text { Empiris }\end{array}$ & $\begin{array}{l}\text { Sebaran } \\
\text { Teooritis }\end{array}$ & $\begin{array}{l}\text { Sebaran } \\
\text { Empiris }\end{array}$ \\
\hline $\begin{array}{l}\text { Karyawan } \\
\text { yang dipimpin } \\
\text { oleh lokal }\end{array}$ & 36 & 145 & 177,53 & 29 & 21,513 & $58-232$ & $142-232$ \\
\hline $\begin{array}{l}\text { Karyawan } \\
\text { yang dipimpin } \\
\text { oleh }\end{array}$ & 36 & 145 & 183,03 & 29 & 24,158 & $58-232$ & $122-232$ \\
Ekspatriat & & & & & & & \\
\hline
\end{tabular}


Tabel 2

Rangkuman Uji Hipotesis Penelitian

\begin{tabular}{clc}
\hline No & \multicolumn{1}{c}{ Hipotesis Penelitian } & Hasil \\
\hline 1 & $\begin{array}{l}\text { Hipotesis Nol: } \\
\text { Tidak terdapat perbedaan kepuasan kerja karyawan } \\
\text { hotel yang dipimpin oleh pemimpin ekspatriat dan } \\
\text { pemimpin lokal. }\end{array}$ & Diterima \\
\hline 2 & $\begin{array}{l}\text { Hipotesis Alternatif: } \\
\text { Terdapat perbedaan kepuasan kerja karyawan hotel } \\
\text { yang dipimpin oleh pemimpin ekspatriat dan } \\
\text { pemimpin lokal. }\end{array}$ & Ditolak \\
\hline
\end{tabular}

